Nataša M. Vukićević

University of Kragujevac

Faculty of Education in Jagodina

Department for Didactics and Methodology

Vesna M. Petrović

Department for Human Sciences
УДК 78.087.6-053.4

https://doi.org/10.18485/uzdanica.2020.17.1.22

Оригинални научни рад

Примљен: 28. фебруар 2020.

Прихваћен: 1. јун 2020.

\title{
DEVELOPMENT OF TONE PITCH PERCEPTION IN CHILDREN OF YOUNG AGE BY APPLYING MULTIMODAL APPROACH ${ }^{1}$
}

Abstract: This paper presents the results of an experimental research that examines the effects of a multimodal approach, compared to the usual approach, to the development of abilities to distinguish tone pitches in children aged 5;6-6;0. The experimental program was designed by combining four principles: known music material, two tone pitches, spatial-visual coding of pitches by means of pictorial notes, and pitch coding through movement of hands. The sample included 83 children - 39 in experimental and 44 children in control group. After the completion of the experimental program, the results have shown that the experimental group significantly improved in distinguishing tone pitches compared to the control group. The analysis has shown that the main psychological mechanism of progression was conveying auditory information through motor and pictorial signs, followed by their internalization into the inner mental plan in the form of music representations.

Keywords: tone pitch, cognitive tool, learning music, early age.

\section{INTRODUCTION}

The process of learning music can be divided into two phases, the preparatory phase and the phase of musical literacy. According to Gordon (2012), the earliest possible onset of systematic action on a child's musical development, precisely in the preparatory phase is crucial for the whole process of music education. Pursuant to the interpretation of various authors, we can conclude that the main direction of music perception moves from sensory and emotional aspect to intellectual one, consciously directed listening to music. Blaškovic and Kuliš (2017) indicate that physiologically, sensory and emotional aspects represent important components of reacting to music, and sometimes they can be sufficient by themselves. However,

${ }^{1}$ This research was funded by the Ministry of Education, Science and Technological Development of the Republic of Serbia (Contract No. 451-03-68/2020-14/ 200140). 
when these aspects of reacting to music are not connected and improved through integration with cognitive one, we cannot speak about the ability of listening. In such case, even the music experience itself does not have artistic, esthetic, and symbolic value for an individual. The transition from sensory and emotional to intellectual listening is defined by various authors as a transition from passive to active listening (Sam 1998, as cited in Blaškovic, Kuliš 2017), from perceptive to analytical (Borota 2006), from motor, associative to cognitive listening or acquisition of abilities (Rauhe 1972, as cited in Blaškovic, Kuliš 2017).

In the preparatory phase of musical learning or more precisely musical perception, systematic training of children in discrimination of tone pitches should have a central place. According to Mirković-Radoš (1998), distinguishing tone pitch is important as a preparation for understanding melodic flow, movement of melody, reading note text, reproduction of melody, and understanding other dimensions of music. Tone pitch, as its basic characteristic, to a great extent determines what we will remember and "what would be our emotional reaction to a certain tone" (Seashore 1938: 63, as cited in Mirković-Radoš 1998: 42).

The children almost at birth differentiate tone pitches at the level of sensory sensations. Denac (2012, cited in Blaškovic, Kuliš 2017) states that, for example, in infants a change in tone pitch causes the appearance of orientation reflex, i.e. change at the physiological level such as changes in facial expression, heart bits and similar. However, in order for the children to master the perception of tone pitches in a willing and conscious way, it is necessary to have a maturation occurred in the next five years of life and, as previous research have shown - specific, musical training at the end of early childhood.

Until the end of the fifth year, children have difficulties in distinguishing tone pitches, which is manifested, among other things, by the characteristic monotonous singing, i.e. the inability to reproduce accurately the melody line. Jordan-DeCarbo (1989) has researched the influence of various methodological approaches to the development of discrimination of tone pitch in children aged 3, 4, and 5. According to her main results, regardless of methodological approach, five-year-olds achieved significantly better results in perception of tone pitch than three-year-olds and fouryear-olds, while the differences between three-year-olds and four-year-olds did not exist (Jordan-DeCarbo 1989). Finally, observed in relation to the development of the ability to identify other traits of tone, the mastery of conscious perception of pitch comes delayed and subsequently.

Thus, as in the development of general music ability of listening, the development of tone perception begins as a simple sensory sensitivity, and in correctly directed music learning it should develop in direction of awareness and willingness. In theoretical definitions of music listening or discrimination these two processes were also clearly identified as its important components. As stated by Wolvin and Coakley (1982, as cited in Blaškovic, Kuliš 2017), listening to music is a process that includes hearing, directed attention and giving meaning to what is heard. 
Difficulties in examining the distinguishing tone pitch in children. In examinations of children's ability to distinguish tone pitch, several important methodological constraints have been identified that have a source in the developmental characteristics of children in young age: communication barriers, lack of verbal ability to mark, and then to express the experienced, limitations in the development of general psychic functions such as attention and memory. In relation to this, the authors offered the appropriate methodological solutions.

From easier to more difficult tasks. In the order of setting the tones, different authors respect the principle from easier to more difficult tasks. Respecting this principle is reflected in the setting of a stimulus on a descending scale. For example, in Seashore's tests of distinguishing pitches it is examined whether the second tone in the pair is higher or lower than the previous one (Seashore 1938). Buckton (1982, as cited in Briggs 1991) also recommends comparison of higher and lower tone, while with Bentley (1966, as cited in Mirković-Radoš 1998), respondents rate whether the second tone is higher, lower, or the same. However, in terms of pitch differences between consecutive tones, the recommendation of these authors is to go from larger differences in pitch to smaller intervals.

Absence of relational thinking. In other studies, Zimmerman (1971, as cited in Mirković-Radoš 1996) and Briggs (1991), as a factor hindering the objectivity of testing the pitch discrimination ability, identified inadequate research technique or the requirement for the child to report verbally pitch differences, and to answer whether the tone he/she heard was "high" or "low". In an early age, children are not able to understand relative meaning of the concepts high-low. For them, these terms denote the absolute and fixed characteristics of the objects they learn through their practical-visual experience. Hence, Sergeant (1973) suggests delaying the use of the terms high and low, and replace them with the task to distinguish if two tones are the same or different.

Taking into account developmental characteristics in general psychic functions. Listening to music is an integral part of psychic activities and it represents an expression of characteristics and degrees of development of general psychic functions. This means that when selecting tunes for testing purposes, it is necessary to take into account those tuning characteristics that spontaneously attract and retain the attention of a preschooler on a particular subject, and allow for better memorization. For the same reason, the factor of the compatibility of the task with the musical context and the natural learning situation in the music activities appears as an important factor in examining the tone pitch difference in the research results of Sergeant (1973), Wallentin (2010), Fyk (1995), Gordon (2012). According to these authors, the children in early age can identify melody and discover its meaning based on the movement of tune. Therefore, Fyk (1995) states the characteristics of tunes that are easier for children to perceive and associate with positive emotions are: descending melody, treble, small range of two or three tones, simple melody in the form of repetition. 
Furthermore, what makes it easier for children to understand tone pitch is the closeness of intonation in words with musical intonations. Sternberg (1998) considers that the common features of speech intonation and musical expression indirectly, through emotional arousal/response and child engagement, enable better understanding and differentiation of tone pitch.

Crowter, Durkin, Shire and Hargreaves (1985), in the research of perception of music concepts in preschool age, came to conclusion that the tasks on known music material are more successful resolved when the children's songs are used in the examination.

Multimodal encoding. The observed regularity that musical perception in children improves when the music stimulus is supported by visual and motor representation has been confirmed in a large number of studies (Shanks 2003; Ebendorf 2007; Boltz, Ebendorf, Field 2009). The visual representation of auditory content in the form of an image or movement is an unavoidable stage of the methodical process in working to introduce music concepts that "should be prepared in the form of immediate experience" (Plavsa 1989: 72). The children have task to experience the difference in tone pitches through play and by using "rhythmic images" that represent the tone durations and pitches on a system of one to three horizontal lines, to experience the occurrence, development and flow of the song's melody (Plavsa 1989). Other studies, however, have addressed the problem of providing answers on music tests when it comes to preschool age. Their authors Boyle (1992, as cited in Plavsa 1989) and Simons (1974, as cited in Plavsa 1989) have recommended the use of non-verbal tone pitch reporting techniques by using a visual sign while Andrews and Deihl (1967, as cited in Plavsa 1989) have recommended the use of hand movement.

Most authors explain the stated results by fundamental fact of children's psychic functioning according to which it is naturally holistic, i.e. at the same time visual, motor, cognitive, linguistic and emotional. They emphasize that combining auditory and visual medium and the use of several different stimuli (image, movement) can improve cognitive processes of children in area of music learning (Campbell 2004; Jordan-DeCarbo, Galliford 2001; Hallam 2006; Liduma 2016). "This process of perception and experiencing music and movement activities has a physiological basis in the brain coordination of the areas responsible for anticipation and association of auditory and movement mages" (Kolodziejski, Králová 2016: 187).

Multimodal approach to music learning has another significant developmental-formative dimension, which has not been sufficiently perceived and explained in the pedagogical literature. According to Vygotsky (1996), all psychic functions occur in two basic forms - lower and higher. Lower functions are developing through processes of biological maturation of brain; they are not under voluntary control of the person and their cognitive ranges are limited. Higher functions have thoughtful and willing character (voluntary attention, voluntary memory, logical thinking); a 
person uses them in a conscious, and towards aim directed way. What is key for the development of higher psychic functions is that they are of social origin and occur through a process of internalization of cultural artifacts such as various systems of signs (among which the most important is language) into the internal, mental plan of an individual. In this way lower or primary psychic functions are transformed and improved to the level of consciousness and willingness, and abstract contents and meanings become available for cognition (Vigotski 1996). For example, general psychic functioning of a child is significantly improved when a child starts to understand language and "the child begins to perceive the world not only through his eyes but also through his speech" (Vygotsky 1978: 32).

Keeping in mind the vygotskian framework of the interpretation of general psychic development, it is also inevitable in area of development of music abailities we find artificial and mediated development as a natural tendency of human development. In early ages, as we already mentioned, the function of mediator of auditory information may belong to - movement, image or objects, gestures, verbal description, etc.

Regularity that music perception of tone pitches in children in early age is improved when a musical stimulus is supported by visual representation was noticed as early as in 1930s in the research of Russian authors Rjepina (1956, as cited in Zaporožec, Eljkonjin 1967) and Endovickaya (1955, as cited in Zaporožec, Eljkonjin 1967).

In tests of Endovickaya, it was supposed that children during playing handle their estimation of differences in pitch of two tones, whether the derived tones are the same or different. The task was successfully resolved only by children older than 5. However, the same children had difficulties when they should establish the direction of tone pitch change - whether the second tone is higher or lower than previously set. Rjepina and Endovitskaya report that the children succeeded in distinguishing direction of tone pitch change, and to verbally indicate which tone is higher in the pair of set tones after a special training in modeling and active reproduction of the relation of tone pitches by means of other sensory systems. Rjepina (1956, as cited in Zaporožec, Eljkonjin 1967) trained children to distinguish between relations of tones by pitch in the way that they were connecting them among the sizes of objects they perceived visually. High tones were conditionally connected to voices of small animals, and low ones with voices of large animals. The children in playing performed visual and motor spatial reproduction of tones by pitch, and after that they were able to distinguish between tones by pitch without external, visual support.

Considered through Vygotskian framework of interpretation, what in such programs of training enables development of discrimination in children is exactly the mechanism of mediation and internalization. Through a specific training, external signs such as movement or image point out the feature of cognitive tools by means of which the children master their own processes of listening, and then 
discover meanings that are not available to immediate auditory perception. Borota (2006) considers that these cognitive tools enable construction of music mental representations, and the improved ability of listening remains even when visual support is physically removed.

The development of abilities for discrimination of tone pitch is a component part of the majority preschool curricula, while the activity or singing by ear has one of the main roles in training programs for preschoolers (Rulebook on general basics of preschool program 2006). In the literature, however, the considerations of the question if the task of developing abilities for discrimination of tone pitch would be more appropriate and have priority in the order of learning in relation to singing by ear (Jordan-De Carbo 1989).

In this paper we are dealing exactly with the problem of approach to development of ability to distinguish tone pitch and its theoretical basis in rules of general psychic, musical, and cognitive development of children in early age. We hold that uncovering and theoretical explanation of learning processes leading from direct and spontaneous to indirect and conscious processing of auditory information would be relevant for further research of children's musical development, and that it would significantly improve the praxis of music pedagogues, educators.

\section{METHODOLOGY OF RESEARCH}

In this paper we are adressing the problem of influence on discriminating tone pitch in children at an early age by means of multiple encoding of auditory information - through vision, voice, and bodily movement. The research aims to examine if and to which extent the use of multiple encoding of information in the development of tone pitch perception in children provides better results compared to the usual way of carrying out music activities in preschool institutions.

Sample. The research was carried out in the Preschool institution "Pionir" in Jagodina in the period April-June 2019. The sample included 83 children aged $5 ; 6-6 ; 0$. The experimental group consisted of 39 children and the control group consisted of 44 children.

Instrument and procedure of examination. In the initial and final test the tasks were equable according to difficulty. Each of the three tasks represented a pair of tones that make various consonant intervals (descending perfect fifth, descending major sixth, and ascending perfect fourth in the initial text, and descending major sixth, descending minor third and ascending perfect fifth in the final text) (Figures 1 and 2). In the testing only three pairs of tones were used, taking into account developmental limitations of six-year olds in duration of attention. After listening to broken down intervals in vocal performance of the experimenter, a subject needs to identify if the first tone in the pair is higher than the other one, and to show the pitch by the appropriate movement of hand. 
Figure 1. Initial test of distinguishing higher and lower tone in a pair

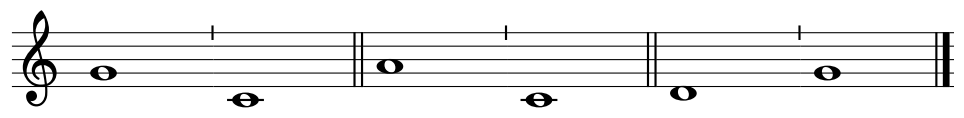

Figure 2. Final test of distinguishing higher and lower tone in a pair

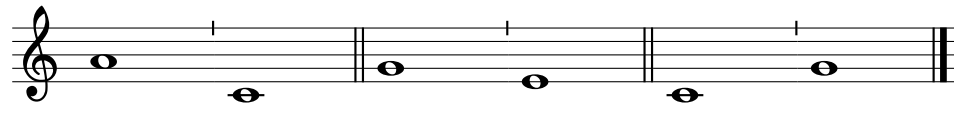

Before the initial test, in order to equalize initial knowledge in the control and the experimental group, the children went through the preparation part of renewing knowledge on difference between sound and tone (listening to sound examples), and the knowledge of spatial relation of up and down (hand position up and down).

The final test was preceeded by practicing technique applied in testing, at tone pitches within melodic phase with certain tonal centre (Figure 3). Final testing included measuring immediate effects and it was performed seven days after the completion of the experimental program.

Figure 3. Preparatory exercise for recognition of higher and lower tone in the pair
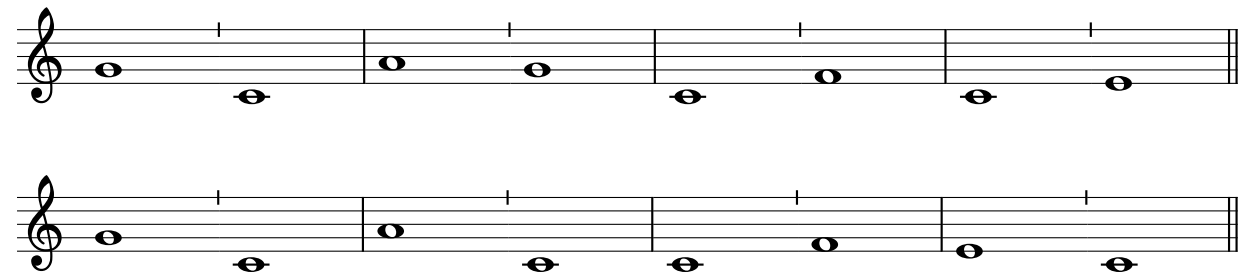

Experimental program. When selecting music contents and activities for the experimental program, the following principles that were singled out in various research studies as factors contributing to the improvement of direct perception of tones in children at an early age were took into account: 1. music material known to the children, 2. two tone pitches, 3. spatial-visual representations of pitches by means of pictorial notes, and 4. pitch encoding, through simultaneous vocal reproduction and bodily movement of hands up-down.

The activities in the experimental program were carried out in two segments during two weeks, i.e. in total twice, once a week in duration of 30 minutes each time.

Within the first segment, the order of activity was the following. In the introduction part the children sang with the experimenter a song called Birthday song that has already been well known to them (Figure 4).

During the following activity, the experimenter sang alone and marked various tone pitches with hand movements while the children were asked to listen and 
Figure 4. Tune of Birthday song

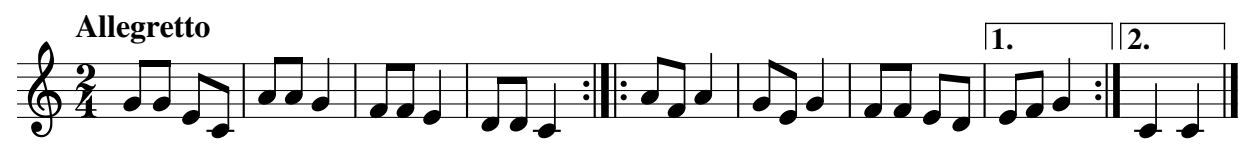

observe the experimenter's performance. Motor encoding of auditory information, tone pitches for the first part/stanza of the song was shown in the Table 1. In the last activity, after it was demonstrated once, the children were asked to follow the song tune (in relation to the initial verse of each verse) by hand movements in the same way. With verbal explaining and correcting children's performance within the framework of envisaged activities, the children were taught to link movement up with high tones and movement down with low tones. The movements for the refrain melody were conceptualized by analogical procedure.

Table 1. Motor Encoding of Various Tone Pitches - Higher/Lower Tone Compared to previous one, i.e. encoding of melody movement of Birthday song

\begin{tabular}{ll}
\hline Music Information & Motor Symbol \\
\hline Motive beginning with the tone G (G G E C) & Clapping hands \\
$\begin{array}{l}\text { Motive beginning with a higher tone } \\
\text { compared to previous (A A G) }\end{array}$ & By snapping hands raised at head height \\
$\begin{array}{l}\text { Motive F F E, with lower initial tone } \\
\text { compared to the previous }\end{array}$ & $\begin{array}{l}\text { They lower their hands again clapping their } \\
\text { hands } \\
\text { Lowest tones of the first verse (D D C) }\end{array}$ \\
& $\begin{array}{l}\text { By further lowering hand and by striking } \\
\text { palms onto thighs }\end{array}$ \\
\hline
\end{tabular}

Within the second segment, the children were practicing distinguishing tone pitch on a song At the end of the village that they already knew. After listening to the performance they should look up to, the children learned the song by means of pictorial notes. The first task was singing a song together with simultaneous following of symbols on the board, and then the children individually showed the "pictorial notes" they were singing at that moment (Table 2). In accordance with children's previous experiences when processing song and with the volume of tune consisting of three various tones (E F G), pictorial notes were shown on a line. Each tact was represented on a separate sheet. A system with image of one object (yellow house) was used, so that the variety of symbols does not draw the attention of the children in the other direction.

Table 2. Pictorial Encoding of Tones of the Song at the End of the Village

\begin{tabular}{ll}
\hline Music information, stimulus & Pictorial marking, symbol \\
\hline Tone E & Image of yellow house under the line \\
Tone F & Image of yellow house on the line \\
Tone G & Image of yellow house above the line \\
\hline
\end{tabular}


The following task in this segment was the perception of higher and lower tones and visual representation by means of prepared applications that should be put onto the appropriate place under or above the line marked on the board. After these common activities, the children had a task to glue, on their sheets with drawn line in the middle, a sticker above the line when they hear a higher tone and under the line when they hear a lower tone.

In both segments the children obtained feedback; the experimenter repeated certain music phrases and movements, and corrected children's motor performance.

\section{RESULTS}

Initial test. The results at the initial test show that the children from the experimental and the control group were equally successful in identifying tone pitches in each of the three test tasks $\left(\chi^{2}(\operatorname{task} 1)=0.1, p>.01\right), \chi^{2}(\operatorname{task} 2)=0.004, p>.01$; $\left.\chi^{2}(\operatorname{task} 3)=0.0, p>.01\right)$. Additionally, pursuant to frequencies it can be concluded that the children in both groups were better in identifying tone pitch in descending than in ascending interval (Table 3).

Table 3. Comparative Review of the Results of Experimental and Control Group at the Initial Test

\begin{tabular}{|c|c|c|c|c|c|c|c|}
\hline \multirow{2}{*}{$\begin{array}{l}\text { Tone pairs } \rightarrow \\
\text { Groups of } \\
\text { respondents } \downarrow\end{array}$} & \multicolumn{2}{|c|}{$\begin{array}{l}\text { First pair of tones } \\
\text { (higher-lower) }\end{array}$} & \multicolumn{2}{|c|}{$\begin{array}{l}\text { Second pair of tones } \\
\text { (higher-lower) }\end{array}$} & \multicolumn{2}{|c|}{$\begin{array}{l}\text { Third pair of tones } \\
\text { (lower-higher) }\end{array}$} & \multirow{2}{*}{$\frac{\Sigma}{f(\%)}$} \\
\hline & $\begin{array}{c}\text { Correct } \\
f(\%)\end{array}$ & $\begin{array}{c}\text { Incorrect } \\
f(\%)\end{array}$ & $\begin{array}{c}\text { Correct } \\
f(\%)\end{array}$ & $\begin{array}{c}\text { Incorrect } \\
f(\%)\end{array}$ & $\begin{array}{c}\text { Correct } \\
f(\%)\end{array}$ & $\begin{array}{c}\text { Incorrect } \\
f(\%)\end{array}$ & \\
\hline E groupa & $\begin{array}{c}20 \\
(51,28)\end{array}$ & $\begin{array}{c}19 \\
(48,72)\end{array}$ & $\begin{array}{c}29 \\
(25,64)\end{array}$ & $\begin{array}{c}10 \\
(74,36)\end{array}$ & 0 & $\begin{array}{c}39 \\
(100)\end{array}$ & $\begin{array}{c}39 \\
(100)\end{array}$ \\
\hline $\mathrm{C}$ group $b$ & $\begin{array}{c}21 \\
(47,73)\end{array}$ & $\begin{array}{c}23 \\
(52,27)\end{array}$ & $\begin{array}{c}33 \\
(75)\end{array}$ & $\begin{array}{c}11 \\
(25)\end{array}$ & 0 & $\begin{array}{c}44 \\
(100)\end{array}$ & $\begin{array}{c}44 \\
(100)\end{array}$ \\
\hline
\end{tabular}

${ }^{a} \mathrm{E}$ group $=$ Experimental Group ${ }^{b} \mathrm{C}$ group $=$ Control Group

Postexperimental test. In postexperimental testing, the children from the control group did not show significant progression compared to the results obtained on the initial test $\left(\chi^{2}(\operatorname{task} 1)=0.73, \mathrm{p}>.01, \chi^{2}(\operatorname{task} 2)=0.5, \mathrm{p}>.01\right), \chi^{2}(\operatorname{task} 3)=$ $2,05, \mathrm{p}>.01)$. In addition, on the postexperimental test, the children from $\mathrm{C}$ group maintained the tendency to identify better the tone pitches when they were set in descending interval (Table 3).

In postexperimental testing, the children from the experimental group have shown significantly better results in recognizing tone pitch compared to the initial test on all three tasks $\left(\chi^{2}(\right.$ task 1$)=25.12, \mathrm{p}<.01, \chi^{2}(\operatorname{task} 2)=11,47, \mathrm{p}<.01$, $\left.\chi^{2}(\operatorname{task} 3)=60,27, \mathrm{p}<.01\right)$. Moreover, children from the experimental group progressed significantly in the third task, in recognition of tone pitch in ascending interval, and by that result they equalized with the results in the first two tasks.

Comparison between the two groups. Comparing the results of two groups, a simple overview of the table already gives an insight into the indisputable advantage 
Table 4. Comparative Review of the Results of Experimental and Control Group at the Final Test

\begin{tabular}{|c|c|c|c|c|c|c|c|}
\hline \multirow{2}{*}{$\begin{array}{l}\text { Tone pairs } \rightarrow \\
\text { Groups of } \\
\text { respondents } \downarrow\end{array}$} & \multicolumn{2}{|c|}{$\begin{array}{l}\text { First pair of tones } \\
\text { (higher-lower) }\end{array}$} & \multicolumn{2}{|c|}{$\begin{array}{l}\text { Second pair of tones } \\
\text { (higher-lower) }\end{array}$} & \multicolumn{2}{|c|}{$\begin{array}{l}\text { Third pair of tones } \\
\text { (lower-higher) }\end{array}$} & \multirow{2}{*}{$\frac{\Sigma}{f(\%)}$} \\
\hline & $\begin{array}{c}\text { Correct } \\
\mathrm{f}(\%)\end{array}$ & $\begin{array}{c}\text { Incorrect } \\
\mathrm{f}(\%)\end{array}$ & $\begin{array}{c}\text { Correct } \\
f(\%)\end{array}$ & $\begin{array}{c}\text { Incorrect } \\
\mathrm{f}(\%)\end{array}$ & $\begin{array}{c}\text { Correct } \\
\mathrm{f}(\%)\end{array}$ & $\begin{array}{c}\text { Incorrect } \\
f(\%)\end{array}$ & \\
\hline E group ${ }^{a}$ & $\begin{array}{c}39 \\
(100)\end{array}$ & 0 & $37(94,87)$ & $\begin{array}{c}2 \\
(5,13)\end{array}$ & $34(87,18)$ & $\begin{array}{c}5 \\
(12,82)\end{array}$ & $\begin{array}{c}39 \\
(100)\end{array}$ \\
\hline$C$ group $^{b}$ & $\begin{array}{c}34 \\
(77,27)\end{array}$ & $\begin{array}{c}10 \\
(22,72)\end{array}$ & $\begin{array}{c}36 \\
(81,82)\end{array}$ & $\begin{array}{c}8 \\
(18,18)\end{array}$ & $\begin{array}{c}2 \\
(4,55)\end{array}$ & $\begin{array}{c}42 \\
(95,45)\end{array}$ & $\begin{array}{c}44 \\
(100)\end{array}$ \\
\hline
\end{tabular}

${ }^{a} \mathrm{E}$ group $=$ Experimental Group ${ }^{b} \mathrm{C}$ group $=$ Control Group

of the experimental compared to the control group. Statistically significant differences in favor of the experimental group were found in all the tasks $\left(\chi^{2}(\operatorname{task} 1)=\right.$ $\left.21,84, \mathrm{p}<.01), \chi^{2}(\operatorname{task} 2)=14.93, \mathrm{p}^{<} .01, \chi^{2}(\operatorname{task} 3)=57.48, \mathrm{p}<.01\right)$. The most pronounced differences in the results between the two groups were obtained in the third task, i.e. in recognizing the tones by pitch in the ascending interval.

\section{DISCUSSION}

Based on the results it can be concluded that the experimental training enabled children to achieve significantly better results compared to the control group. The methodology of research that was presented in this paper offers the possibility to interpret the data from the point of view of socio-constructivist ideas of Vygotsky as well. The order in which descending and ascending intervals were set - the first and the second - descending, and the third - ascending interval, is important for the interpretation (Figures 1 and 2).

In the postexperimental examination, by setting tones within the first two descending intervals, in the control group of children it was expected that the third interval will also have the same, descending direction. The presence of this implicit expectation was clearly recognized in the results of the control group. Namely, in the third task, the children from the control group repeated "by heart" and without delay hand movements up, and then down - indicating descending instead of presented ascending interval, i.e. most of the children did not answer correctly -42 of them $(95,45 \%)$ (Table 4). On the other side, in the experimental group, most of the children correctly identified tone pitches in the ascending interval - 34 $(87,18 \%)$, i.e. they did not follow the first impulse to repeat the previous order of moves (Table 4).

Therefore, delay of the first answer and willing direction of attention to set pairs of tones, can be clearly recognized only in postexperimental answers of the children from the experimental group. The presence of these qualities explains better accomplishment of the experimental group; better accomplishment can be attributed to stepping forward out of the level of sensory listening. As already 
mentioned, the ability to identify tone pitches in descending interval, and inability to distinguish tone pitches in ascending interval represents a type of developmental norm for six-year olds (Seashore 1938). Ortman (1927, as cited in Blasković, Kuliš 2017), as well as other authors we mentioned in the introductory part, defines the ability of music listening exactly through the quality of willingness, directed listening and correct identifying. Ortman differentiates three basic ways of hearing - sensory, perceptive and imaginative listening (Blasković, Kuliš 2017). For this research the first two are significant. At the lowest, sensory level of listening, sensory answer demands minimum mental effort, and absence of any intellectual engagement. "Perceptive type of reaction implies noticing progressions, sequences, motives, phrases, contrasting forms and alike" (Blašković, Kuliš 2017: 276). According to Lehmann, Sloboda and Woody (2007), unlike the sensory, at the perceptive level willing attention and ability for cognitive processing of relevant music information were present.

The results of this research are in accordance with the results of Jordan, who experimentally, in training three-year-olds, four-year-olds, and five-year-olds to discriminate tones by pitch, used as mediators - images of various shapes, sizes, and color. Jordan reports that the experimental group of five-year-olds progressed compared to the control group, although this progression was not statistically significant. Compared to Jordan's, our research is different in two significant aspects. The respondents were a year older (maturity is important variable in examination of discrimination at this age). As the second, unlike Jordan-De Carbo (1989) who, in her experimental program, used only visual, perceptive representations, we used visual and motor ones as well. However, what is common in both experimental approaches to teaching is mediation of the listening process by means of signs from other modalities of visual or visual and motor.

In Vygotskian interpretation, developmental mechanism contained in our experimental program (and other programs based on multimodal approach) consists in mediation of direct psychic processes by means of external sign, and then in its internalization into inner mental plan of an individual. "But the structure of sign operations requires an intermediate link between the stimulus and the response. This intermediate link is a second order stimulus (sign) that is drawn into the operation where it fulfills a special function; it creates a new relation between $\mathrm{S}$ and $\mathrm{R}$. The term 'drawn into' indicates that an individual must be actively engaged in establishing such a link" (Vygotsky 1978: 39). In children's behavior in our research, it was observed that hand movements down, that were simultaneously trained with listening to music, became a means or tools for (self)mobilization of child's effort and cognition in relation to set tones (auditory stimuli).

Due to natural ability of human brain for allomorphic development (Vigotski 1996), these mediators, which at first look like external support to listening to tones, through a process of repetition are integrated with the process of sensory listening, and, at the same time, they modify it, transform it. This integration at mental plan 
leads to the construction of a brand new cognitive structure - musical representation (Borota 2006). These new cognitive structures function as a cognitive tool for reception and interpretation of auditory information.

\section{CONCLUSION}

This paper examined the influence of the procedure of multiple encoding of auditory information on the development of tone pitch discrimination in six-year olds. In the final testing, seven days after the completion of the experimental program, the experimental group of children, compared to the control one, achieved significantly better results regarding the discrimination of tones within the framework of descending and ascending intervals, i.e. it improved its own process of listening from purely sensory to a conscious and willing one. Pursuant to analysis of the obtained results, on the one side, it can be concluded that the changes were made at mental plan, i.e. within the process of listening and identifying tone pitch itself. Expressed by Vygotskian vocabulary - through experimental training, hand movements up-down obtained a feature of auditory-motor tool. The children from the experimental group learned to use motor symbols as cognitive tools for organizing two key processes of listening - a) delay of the first response (willing direction of attention to what is heard), and b) perception and identifying relation between tones - higher and lower tone, which has transformed an unconscious and direct process of perception of tones in children into a voluntary listening and identifying the same music stimuli. Our research plan did not include testing delayed effects of the applied experimental program. Even so, we believe that the effects of the program are sufficiently indicative in terms of the possibility of influencing abilities of listening in children through specific training programs.

\section{REFERENCES}

Блашковић, Кулиш (2017): Jelena Blaškovic, Ana Kuliš, Preschool Children’s Reactions to Active Music Listening through Movement, Visual Arts and Verbal Expression, Croatian Journal of Education, Vol. 19, Sp. Ed. No. 3/2017, Zagreb: Faculty of Teacher Education, University of Zagreb, 273-292.

Борота (2006): Bogdana Borota, Vloga simbola pri razvijanju glasbene predstavljivosti v zgodnjem obdobju, In: V. Medved Udovič, M. Cotič, D. Felda, (Ur.), Zgodnje učenje in poučevanje otrok 2, Koper: Univerza na Primorskem Pedagoška fakulteta Koper, 543-552.

Бригс (1991): Cinthya Briggs, A Model for Understanding Musical Development, Music Therapy, 10 (1), 1-21.

Кемпбел (2004): D. L. Campbell, Attention focus of college music and non-music majors during music listening, Proceedings of the 8th International Conference and $\mathrm{Mu}$ sic Perception \& Cognition, ICMPC8, Evenston, IL, 474-477. Преузето априла 2020. 
ca cajта: https://www.tib.eu/en/search/id/BLCP\%3ACN070120779/Attention-Focus-ofCollege-Music-and-Non-Music/

Краутер, Даркин, Шајер, Харгрејвс (1985): Robert Crowther, Kevin Durkin, Beatrice Shire, David Hargreaves, Influences on the development of children's conservation-type responses to music, Bulletin of the Council for Research in Music Education, No. 85, University of Illinois Press, 26-37.

Фајк (1995): Janina Fyk, Musical determinants of melodic contour recognition: Evidence from experimental studies of preschooler, Bulletin of the council for research in Music Education, 127, 72-79.

Гордон (2012): Edwin E. Gordon, Learning Sequences in Music: A Contemporary Learning Theory - 2012 edition, Chicago: GIA Publications, Inc.

Халам (2006): Susan Hallam, Conceptions of musical ability, In: M. Baroni, A. R. Addessi, R. Caterina, M. Costa, Proceedings of the 9th International Conference on Music Perception \& Cognition (ICMPC9), Bologna, Italy, 425-433.

Џордан-ДеКарбо (1989): Joyce Jordan-DeCarbo, The Effect of Pretraining Conditions and Age on Pitch Discrimination Ability of Preschool Children, Journal of Research in Music Education, Vol. 37, No. 2, 132-145.

Џордан-ДеКарбо, Галифорд (2001): Joyce Jordan-DeCarbo, Joy Galliford, The effects of a sequential music program on the motor, cognitive, expressive language, social/emotional and musical movement abilities of preschool disadvantaged children, Early Childhood Connections, 7(3), 30-42.

Џордан-ДеКарбо, Нелсон (2002): Joyce Jordan-DeCarbo, Jo A. Nelson, Music and Early Childhood Education, In: R. Colwell, C. Richardson (Eds.), The Handbook of Research on Music Teaching and Learning, A Project of the Music Educators National Conference New York: Oxford press, 210-242.

Колођејски, Кралова (2016): Maciej Kolodziejski, Eva Králová, Music and Movement Activities for Preschool Children to Promote Relationships and Movement Expression, Edukacja Elementarna w Teorii i Praktyce, 11(3(41)).

Леман, Слобода, Вуди (2007): Andreas Lehmann, John Sloboda, Robert Woody, Psychology for Musicians - Understanding and Acquiring the Skills, NY: Oxford University Press, INC.

Лидума (2016): Anna Liduma, Child's musical perception development in early years, Society. Integration. Education, Proceedings of the International Scientific Conference, Volume II, May 27th-28th 2016, 416-425. Преузето априла 2020. са сајта: https://www.researchgate.net/publication/303556679_CHILD'S_MUSICAL_PERCEPTION_DEVELOPMENT_IN_EARLY_YEARS.

Мирковић Радош (1996): Ksenija Mirković Radoš, Psihologija muzike, Beograd: Zavod za udžbenike i nastavna sredstva.

Мирковић Радош (1998): Ksenija Mirković Radoš, Psihologija muzickih sposobnosti, Beograd: Zavod za udžbenike i nastavna sredstva.

Плавша (1989): Dušan Plavša, Muzicko-pedagoske dileme i teme, Novi Sad: Akademija umetnosti u Novom Sadu.

Pravilnik o opštim osnovama predškolskog programa (2006): Beograd: Službeni glasnik - Prosvetni glasnik, br. 1, 14/2006.

Сарџент (1973): Desmond Sergeant, Measurement of pitch discrimination, Journal of Research in Music Education, 21, 3-19. 
Слобода (1978): John Sloboda, Perception of contour in music reading, Perception, 7, 323-331.

Стернберг (1998): Martin Sternberg, American Sign Language Dictionary, 3rd ed., rev. ed., New York: Harper Perennial.

Валентин, Хојлунд Нилсен, Фрис-Оливариус, Вуст, Вуст (2010): Mikkel Wallentin, Andreas Hojlund Nielsen, Morten Friis-Olivarius, Christian Vuust, Peter Vuust, The musical Ear Test, a new reliable test for measuring musical competence, Learning and Individual Differences, 20 (3), 188-196.

Виготски (1978): Lev S. Vygotsky, Mind in society: The development of higher psychological processes, Cambridge, MA: Harvard University.

Виготски (1996): Lav S. Vigotski, Problemi opšte psihologije, Sabrana dela, II tom, Beograd: Zavod za udžbenike i nastavna sredstva.

Запорожец, Ељкоњин (1967): Aleksandr V. Zaporozhets, Daniil B. Elkonin, Psihologija predškolskog deteta, Beograd: Jugoslovenski zavod za prosvetna pitanja.

Цимерман (1971): Marilyn. P. Zimmerman, Musical Characteristics of Children, Reston, VA: Music Educators National Conference.

\author{
Наташа М. Вукићевић \\ Универзитет у Крагујевцу \\ Факултет педагошких наука у Јагодини \\ Катедра за дидактичко-методичке науке \\ Весна М. Петровић
}

Катедра за хуманистичке науке

\title{
РАЗВОЈ ОПАЖАҢА ВИСИНЕ ТОНА КОД ДЕЦЕ РАНОГ УЗРАСТА ПРИМЕНОМ МУЛТИМОДАЛНОГ ПРИСТУПА
}

Резиме: У овом раду испитујемо ефекте мултимодалног приступа у односу на уобичајени приступ обучавању у разликовању висине тонова код деце узраста 5,66,0 година. Експериментални програм је направљен на комбинацији четири принципа: познати музички материјал, две тонске висине, просторно-визуелно кодирање висина помоћу сликовних нота и кодирање висине кроз покрет рукама. Узорком су обухваћена 83 детета - 39 у експерименталној и 44 у контролној групи. Резултати показују да су деца из ЕГ развила способност разликовања висине тонова. Анализе података указују на то да је главни психолошки механизам напредовања био посредовање аудитивних информација преко моторних и сликовних знакова, а потом њихова интернализација на унутрашњи ментални план.

Кључне речи: висина тона, когнитивно средство, музичко учење, рани узраст. 